\title{
POPULATION, MIGRATION, LIVING STANDARD AND SOCIAL PRESSURE: A MODELING APPROACH FROM THERMODYNAMICS
}

Jing Chen*

\begin{abstract}
School of Business - University of Northern British Columbia Prince George, Canada
\end{abstract}

DOI: 10.7906/indecs.11.3.7

Brief report

Received: 25 March 2013.

Accepted: 7 July 2013.

\begin{abstract}
Human societies are complex thermodynamic systems. It is natural to ask to what extent results obtained from simple thermodynamic systems can be extended to provide insights into more complex thermodynamic systems. We apply some simple results from thermodynamics to examine relations among population size, migration patterns, living standard, space, social pressure, and cost to raise children. The result shows that at low levels of living standard, increasing living standard will increase the population size and at high living standard, increasing living standard will decrease the population size. The increase of population size or living standard increases social pressure and pressure to migration.
\end{abstract}

\section{KEY WORDS}

population, living standard, cost of raising children, social pressure

\section{CLASSIFICATION}

JEL: B41, E11, Q01

PACS: 89.65.Cd 


\section{INTRODUCTION}

Biological systems, including human societies, are complex thermodynamic systems. It is natural to ask to what extent results obtained from simple thermodynamic systems can be extended to provide insights into more complex thermodynamic systems. In ecological studies, sizes of animal population and their changes are regarded as the most important indicators of the state of conditions of the animals. Similarly, sizes of human population and their changes are among the most important indicators of the society's wellbeing. In this paper, we will present some simple analytical results from thermodynamics and examine their parallel in human societies. Specifically we will present the results of number of molecules of gases as functions of temperature, space, pressure, and latent heat. Then we use the same analytical relations to examine how population size is related to living standard, space, social pressure, and cost to raise children.

Life is made from non-living materials. But it takes a lot of energy to transform non-living materials into life. Similarly, it takes a lot of energy to transform liquid into gas. We will explore parallels between gas and life, especially human societies. Gases occupy space, exert pressures on each other and the environment, and have temperature, which is a measure of average kinetic energy of gas molecules. In parallel, human beings occupy space, exert pressure to each other and to the environment, and consume energy. The amount of energy consumed is highly correlated with income or living standard. So there is a parallel between temperature and income or living standard. This parallel has already been explored by linking temperature to income in modeling income distribution in human societies [1]. We will apply the state equation of ideal gas to discuss the relations between living standard, space and pressure in human society. Then we will derive a formula for the number of gas molecules as a function of volume, latent heat and temperature, and interpret the formula as the size of human population as a function of available space, cost in raising children and living standard. From the formula, human population is an increasing function of available space and a decreasing function of cost in raising children. The relationship between living standards and human population is more subtle. At a low level of living standard, its increase will increase the population size. After a certain point, the population size will begin to decline with the further increase of living standards. These relationships are consistent with empirical observations [2].

\section{SOME RELATIONS AMONG THERMODYNAMIC VARIABLES AND THEIR APPLICATION TO HUMAN SOCIETIES}

The state equation of an ideal gas is

$$
P V=n R T,
$$

where $P$ is pressure, $V$ is volume, $n$ is the amount of substance, $R$ is a constant and $T$ is temperature. This relation was previously applied to economic activities [3]. In our work, when applied to human societies, let $n$ represent the population of the society, $T$ represent living standard of the society, $P$ represent social pressure and $V$ represent the amount of space occupied by the society. When population or living standard of a society increases, it generates pressure to expand. As a result, living space often expands when a social group's number or living standard increases. Indeed, peaceful migrations and migrations backed by superior military powers characterize the most important events in human history. When migrations are impossible or inadequate, increasing population density and living standard will generate high internal pressure, which will eventually lead to revolution, war, epidemics or the reduction of fertility rate to below replacement rates. Recently, revolutions occured in 
countries where living standard is relatively high, and not in the poorest countries. One may argue that this is because the increase of living standard increases social pressure. In other countries, increasing living standard leads to fertility rates below replacement rate, which lowers the number of population and hence social pressure.

From (1), we have

$$
n=P V / R T \text {. }
$$

To model the transformation from non-living systems to life, we will consider a system contains both liquid and gas. Latent heat is the amount of energy required to transform liquid into gas. Let $L$ represent latent heat per mole of molecule. From a textbook on thermodynamics, such as [4], in equilibrium condition,

$$
P=P_{0} e^{-L / R T} \text {. }
$$

Substituting $P$ from (2) into (1) we obtain

$$
n=\frac{P_{0}}{R} \frac{V}{T} \mathrm{e}^{-L / R T} .
$$

For simplicity, we assume all constants to be one. Then one has

$$
n=\frac{V}{T} \mathrm{e}^{-L / T} \text {. }
$$

Hence $n$ is a function of $V, L$ and $T$. Quantity $n$ is proportional to $V$, the amount of space. This is intuitively clear. $n$ is a decreasing function of $l$, the latent heat. If it takes more energy to turn a specific type of liquid into gas, then there will be less gas molecules in the space. This is also intuitively clear. The relation between $n$ and $T$ is more subtle. When $T$ is small, $n$ is an increasing function of $T$. When $T$ is large, $n$ is a decreasing function of $T$.

In formula (4), the number of gas molecules is a function of volume, latent heat and temperature. To apply the theory to human societies, we had stated earlier that $n$ represent the population size of the society, $T$ represent living standard of the society and $V$ represent the amount of space occupied by the society. We further assume that $L$ represents the cost of raising a child. In physics, the transformation for a molecule from liquid state to gas state is instant. In biological and social systems, the cost of raising children is spread over long term and highly non-trivial to define and measure precisely.

With the reinterpretation of parameters in formula (4), we can discuss the factors that determine the size of human population in a society. First, the size of human population is proportional to available space. This is intuitive enough. Many factors affect the size of the available space that is suitable for human habitat. With higher level of energy input, many of the earlier inaccessible places, due to coldness, hotness or dryness, become hospitable to humans. More energy input and technology also enable human beings to live in multiple level buildings, thus increasing the living space. On the other hand, the depletion of soil or other resources transform the previously fertile land into desolate land.

Second, the size of human population is negatively correlated to the cost of raising children. It can be difficult to determine the factors and their weights adding to the total cost in raising children. An important factor is the age of women giving birth. If women give birth at an earlier age, the cost toward mother, and hence the cost of raising children, is lower. It is also easier for younger women, who are more energetic, to deliver and take care of babies. Therefore, we would expect in a society with lower average age of women giving birth, the population density will be higher. 
Third, at low level of living standard, raising living standard will increase population density; at high level of living standard, raising living standard will decrease population density. A typical graph of population density as a function of living standard, drawn from (4), is shown in Figure 1. At low living standard, raising living standard will provide more food and better nutrition to people so women will become more fertile. Higher living standard also provides better conditions for public health to reduce diseases. When living standard becomes rather high, each member of a society will require large private space and higher energetic activities, such as driving, require large public space. This reduces the maximum population density. The relation between population size and living standard from this analytical model is consistent with empirical patterns. The increase of living standard in poor countries generally generates population growth. The increase of living standard or cost in raising children in rich countries will eventually make their current populations above equilibrium sizes, which will lead to below replacement fertility rates in these countries. This relation between living standard and size of population has important policy implications. It is a universal government policy to raise living standard. At the same time, in most countries with high living standards, where fertility rates are below replacement rate, it is also a universal policy to increase fertility. Our model suggests that these two policies are incompatible. To maintain the replacement fertility, it is necessary to lower living standard in these countries.

The previous discussion assumes that the cost in raising children, living standard and available space are independent variables. However, the cost of raising children depends on the amount of available resources and in turn influences the control and access to resources, which affect living standard and available space. The actual dynamics among different parameters in human societies is much more complex. That dynamics is explored in other works [5-7].

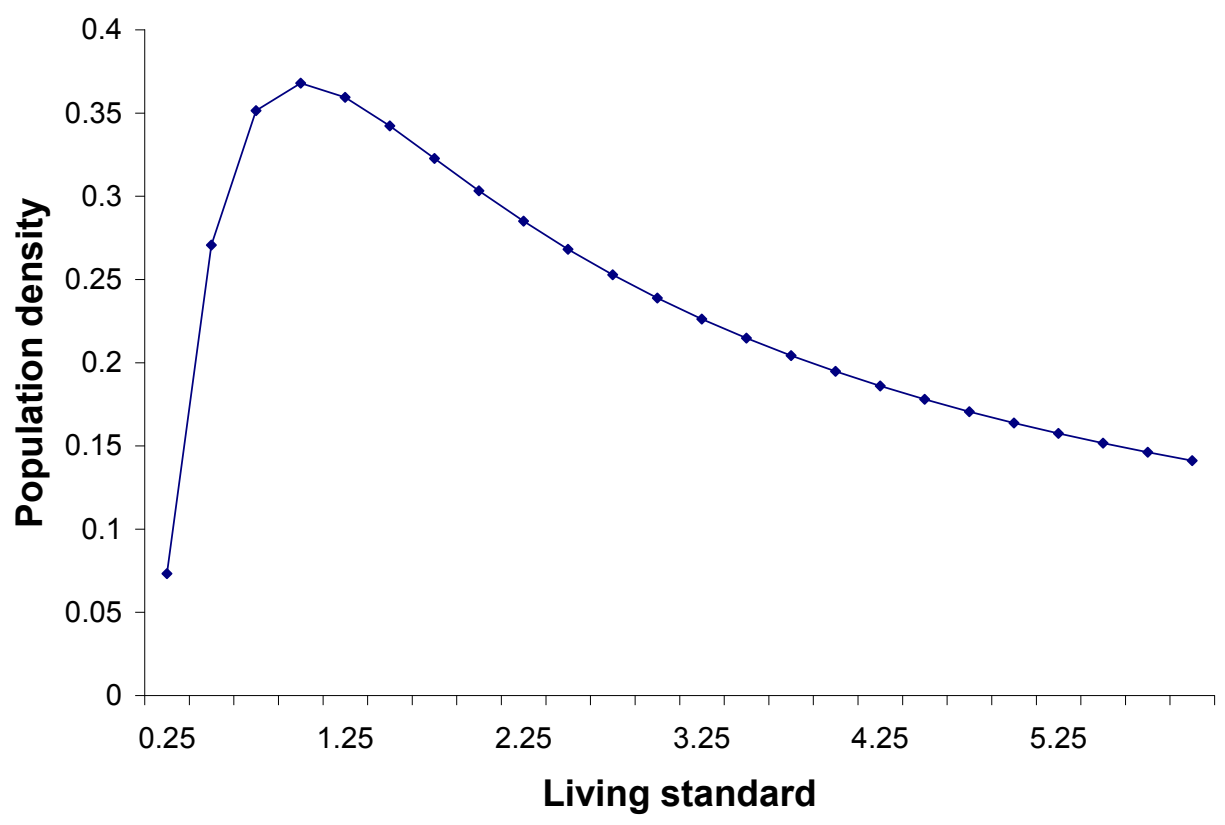

Figure 1. Relation between living standard and population density in equilibrium.

\section{CONCLUDING REMARKS}

In this paper we show that results obtained from simple thermodynamic system can be extended to provide qualitative understanding about more complex thermodynamic systems, such as human societies. We developed an analytical model of human population as a function of available space, cost of raising children and living standard. However, this article 
is an attempt to stimulate further exploration among researchers to understand human societies as physical systems. Much improvement can be made in modeling and interpretation of the analytical results.

\section{ACKNOWLEDGMENT}

I thank John Bryant for helpful comments.

\section{REFERENCES}

[1] Dragulescu, A.A. and Yakovenko, V.M.: Evidence for the exponential distribution of income in the USA.

The European Physical Journal B 20(4), 585-589, 2001,

http://dx.doi.org/10.1007/PL00011112,

[2] Fisher, R.: The genetical theory of natural selection.

Oxford University Press, Oxford \& New York, 1930,

[3] Bryant, J.: A Thermodynamic Theory of Economics.

International Journal of Exergy 4(3), 302-337, 2007,

http://dx.doi.org/10.1504/IJEX.2007.013396,

[4] Reif, F.: Fundamentals of statistical and thermal physics.

McGraw-Hill, New York, p.306, 1965,

[5] Chen, J.: The physical foundation of economics: An analytical thermodynamic theory.

World Scientific, Hackensack, 2005,

[6] Chen, J. and Galbraith, J.: Institutional Structures and Policies in an Environment of Increasingly Scarce and Expensive Resources: A Fixed Cost Perspective.

Journal of Economic Issues 45(2), 301-308, 2011,

http://dx.doi.org/10.2753/JEI0021-3624450206,

[7] Chen, J. and Galbraith, J.: A Common Framework for Evolutionary and Institutional Economics.

Journal of Economic Issues 46(2), 419-428, 2012,

http://dx.doi.org/10.2753/JEI0021-3624460217.

\section{STANOVNIŠTVO, MIGRACIJE, STANDARD ŽIVLJENJA I SOCIJALNI TLAK: MODELIRANJE PRISTUPOM IZ TERMODINAMIKE}

J. Chen

Poslovno učilište - Sveučilište Sjeverne Britanske Kolumbije

Princ George, Canada

\section{SAŽETAK}

Ljudska društva kompleksni su termodinamički sustavi. Prirodno se postavlja pitanje do koje mjere se rezultati opisa jednostavnih termodinamičkih sustava mogu proširiti za dobivanje uvida u kompleksnije termodinamičke sustave. Primijenjeni su jednostavniji rezultati iz termodinamike za ispitivanje relacija između broja stanovnika, obrazaca migracija, standarda življenja, prostora, socijalnog tlaka i podizanja djece. Rezultati upućuju na to kako, pri nižem standardu življenja, njegovim porastom dolazi do povećanja broja stanovnika dok pri višem standardu življenja njegovim porastom dolazi do smanjenja broja stanovnika. Porast broja stanovnika ili standarda življenja povećava socijalni tlak i poticaje za migracije.

\section{KLJUČNE RIJEČI}

stanovništvo, standard življenja, podizanje djece, socijalni tlak 